\title{
Erratum to: Dialysis adequacy in peritoneal dialysis
}

\author{
Giovambattista Virga • Vincenzo La Milia • \\ Giovanni Cancarini $\cdot$ Massimo Sandrini
}

Published online: 4 September 2014

(C) Italian Society of Nephrology 2014

On page S116, in the text of paragraph 4.4, first column, and in the title of Table XI, "required to remove approximately $100 \mathrm{mEq} /$ day" is correct, instead of "required to remove approximately $120 \mathrm{mEq} /$ day".

The original publication (J Nephrol. 2013 Nov-Dec;26 Suppl 21:96-119) can be found at:

http://www.sin-italy.org/web/eventi/SIN/index_rivista.cfm? List=WsTitoloEvento,WsIdEvento\&c1 $=10 \& c 2=00187$

G. Virga $(\bowtie)$

Nephrology and Dialysis Unit, ULSS 15 ,

Camposampiero-Cittadella, Padua, Italy

e-mail: nefrologia@sin-italy.org

V. La Milia

Nephrology and Dialysis Unit, A. Manzoni Hospital,

Lecco, Italy

G. Cancarini - M. Sandrini

Division of Nephrology, A.O. Spedali Civili and University,

Brescia, Italy 